\title{
Språk teller! Om hvordan elever løser, tenker rundt og skriver om et regnestykke
}

\author{
Gro Ulland, Marianne Røskeland og Rune Herheim \\ Høgskulen på Vestlandet
}

\begin{abstract}
In this article, we examine potential relations between writing and understanding in school mathematics. The material consists of 28 student texts in which students from 7 th and 10 th grade solve a mathematical task and write about how they think and how they proceed in order to solve it. In analyzing the student texts, we seek insight into what students emphasize when they individually solve a written assignment. The article is based on experiences from a national priority program on school development, in particular on the competence area "writing as a basic skill". We found that few of the mathematics teachers regarded themselves as writing teachers, which is in line with the prevalent research literature. The analyzes of the student texts show how students position themselves as mathematical writers through their use of language, by the way they explain, and calculate, and how they use different representations. Finally, the relation between explaining and thinking in the student texts is discussed. We find that a combination of calculation and explanatory text provides more information about the student's mathematical understanding and their attitude towards the subject than calculations with numbers alone. In addition, writing can help students develop a professional language and contribute to learning in mathematics. We also document how task design can influence how the students solve a task, and how the students' writing can provide teachers with a better starting point for helping their students learn mathematics.
\end{abstract}

Keywords: Writing; mathematics; student texts; multimodality; mathematical understanding; visualization; positioning; professional language; task formulation

\section{Sammendrag}

I denne artikkelen undersøker vi potensielle sammenhenger mellom skriving og forståelse i matematikkfaget. Materialet består av 28 elevtekster der elever fra 7. og 10. trinn løser en regneoppgave og skriver om hvordan de tenker og går frem for å løse den. Ved å analysere elevtekster har vi søkt innsikt i hva elever vektlegger når de individuelt løser en oppgave skriftlig. Artikkelen har utspring i erfaringer fra satsingen på Ungdomstrinn i utvikling, særlig med kunnskapsområdet skriving som grunnleggende ferdighet. Der viste det seg at et fåtall av matematikklærerne ser på seg selv som skrivelærere, noe som også støttes i forskningslitteraturen. Analysene av elevtekstene viser hvordan elever posisjonerer seg som skrivere i matematikk gjennom språk, forklaringsmåte og utregning, og hvordan de anvender ulike representasjoner. Avslutningsvis diskuteres forholdet mellom å forklare

^Correspondence to: Gro Ulland, Høgskulen på Vestlandet, Postboks 7030, 5020 Bergen. Epost: Gro.Ulland@hvl.no 


\section{G. Ulland, M. Røskeland and R. Herheim}

og å tenke i elevtekstene. Vi finner at en kombinasjon av utregning og forklarende tekst gir mer informasjon om elevens matematikkforståelse og holdning til faget enn utregningen med tall alene. Skrivingen kan dessuten utvikle fagspråk og bidra til læring i matematikk. Vi finner også at selve oppgavedesignet gir føringer for hvordan elevene løser oppgaven. I tillegg kan elevenes skriving gi læreren et bedre utgangspunkt for å veilede elevene i matematikk.

Søkeord: Skriving; matematikk; elevtekster; multimodalitet; matematikkforståelse; visualisering; posisjonering; fagspråk; oppgaveformulering

Recieved: May, 2018; Accepted: September, 2018; Published: October, 2018.

Matematikk er et fag det skrives mye i, både med hverdagsspråk og mer formelt matematisk symbolspråk. Likevel ser matematikklærere sjelden på seg selv som skrivelærere (Bakke, 2014, Jakobsson, 2011, Møller, Prøitz \& Aasen, 2009). Helenius (2017) argumenterer for at det matematiske skriftspråket maner til høy grad av presisjon og ettertenksomhet. Det er derfor vesentlig hva og hvordan det skrives i matematikk. I denne artikkelen ser vi nærmere på betydningen av skriving i matematikk ved å studere elevtekster fra 7. og 10. trinn der elevene løser en regneoppgave og skriver om hvordan de tenker og går frem når de løser den.

Studien undersøker potensielle sammenhenger mellom skriving og forståelse i matematikkfaget når elever arbeider med en relativt lukket tekstoppgave. Ved å analysere elevtekster har vi søkt innsikt i hva elever vektlegger når de individuelt løser en slik oppgave skriftlig. Vi legger særlig vekt på hvordan elevene posisjonerer seg gjennom måten de uttrykker seg på. Dette undersøker vi gjennom analyser av hvorvidt, og i tilfelle hvordan, elevene bruker matematisk språk og visualisering når oppgaven ikke spesifikt etterspør matematisk fagspråk eller visualisering. Vi undersøker også hvordan elevene tolker selve skriveoppdraget.

Med elevtekst forstår vi her både utregning og verbaltekst (den delen av teksten som består av ord), i tillegg til tegninger og andre uttrykksmåter som elevene bruker. Elevteksten inkluderer altså alt elevene skriver som svar på oppgaven. Den delen av matematikkforståelse vi undersøker, handler om det å definere et matematisk problem, argumentere matematisk og se sammenhenger og overganger mellom ulike representasjoner. Å tilegne seg matematisk fagspråk er en viktig del av det å lære faget (se f.eks. Herheim 2016; Johnsen-Høines 2006). I følge internasjonale studier (f.eks. Doerr \& Chandler-Olcott, 2009) og nasjonale studier (Dagsland, 2015) vurderer matematikklærere ofte det å bruke matematiske fagbegreper som indikasjon på matematikkompetanse. Særtrekk ved matematisk fagspråk og tekst beskrives nærmere i et eget avsnitt nedenfor.

\section{Bakgrunn og begrepsrammeverk}

At fagkompetanse og fagspråk generelt henger sammen, er en sentral innsikt innen gjeldende skrive- og språkteori (Martin, 1998a; Martin, 1998b; Karlsen \& Maagerø, 2010). Denne innsikten ligger bak vektleggingen av grunnleggende ferdigheter og 
literacy i LK06 (Berge, 2007), og denne vektleggingen er ytterligere styrket i læreplanrevisjonen i 2013. Av den grunn konsentrerer vi oss primært om skriving i matematikk i norsk sammenheng. Fagets sjangrer, teksttyper og uttrykksmåter blir særlig tydelige i de skriftlige tekstene. Det er derfor god grunn til å studere hvordan elevene bruker språk når de skriver i matematikk. Det er også et poeng i denne artikkelen å undersøke det å bruke skrivedidaktisk perspektiv og forskning på et annet fagfelt, nemlig matematikkdidaktikk. Derfor brukes skrivedidaktiske fagbegreper i analysene.

Det er verdt å merke seg at det å skrive er noe litt annet enn det å snakke. Samtalen har fått en god del oppmerksomhet som et redskap for læring og refleksjon i matematikkdidaktisk forskning i Norge (Nortvedt, 2013; Johnsen-Høines \& Alrø, 2013; Herheim \& Johnsen-Høines, 2016), mens det samme ikke er tilfellet når det gjelder skriving, ifølge Opsahl (2013, 2016). Internasjonalt er det derimot flere studier. Meaney (2012) fant at lærerne mente at elevers skriftlige forklaringer og begrunnelser bidro til dypere matematikkforståelse, og elevene beskrev hvordan skriving støttet deres matematiske tenkning. Albert (2000) argumenterer for at skriving i matematikk er en ressurs for refleksjon som ikke er nok benyttet, og i Pugalee (2004) sin studie var elever som skrev beskrivelser av hvordan de tenkte, betydelig bedre til å løse matematikkoppgaver enn de som bare diskuterte muntlig.

Skriving kan brukes for å systematisere og synliggjøre tanker, og den som skriver til en annen leser enn seg selv, må også ta hensyn til hvordan teksten kommuniserer på en annen måte enn i en samtale der både sender og mottaker er til stede. Skrift kan betraktes som en tenketeknologi, ifølge sakprosaforsker Anders Johansen (2012). Dette er helt i tråd med Misfeldts (2006) doktoravhandling om matematisk skriving. Det er ikke slik at man først tenker ferdig og så skriver det man har tenkt, men selve skrivingen krever bearbeiding av tankene. Man får en distanse til ordene straks de kommer ned på papiret.

\section{Diskurs og posisjonering}

En viktig del av det å lære et fag er som sagt å mestre fagets tekster, språk, arbeidsmåter, argumentasjonsformer og prosesser, som til sammen utgiør fagets diskurs (Gee, 2012). Å vurdere i hvilken grad elever har tilegnet seg matematisk språk, dreier seg om hvorvidt de kan lese, forstå og selv produsere matematikkfaglige tekster. Gee bruker begrepet primerdiskurs om den diskursen som elevene har med seg i hverdagen, mens fagdiskursene er sekundcerdiskurser som elevene må gå inn i for å kunne etablere en faglig identitet ${ }^{1}$. "Primary Discourses constitute our first identity», skriver Gee (2012, s. 137), og danner basisen for hvordan vi møter andre diskurser. Gjennom møte med sekundærdiskurser utvider elevene sitt forråd av tenke- og forståelsesmåter, men også holdninger til det feltet, faget og kulturen som diskursen tilhører.

Vi ser på elevtekstene som ytringer, slik begrepet blir definert av språkfilosofen Michail Bakhtin (2005). Alle ytringer innebærer ifølge Bakhtin å posisjonere seg.

\footnotetext{
${ }^{1}$ Primær og sekundær har ikke nødvendigvis å giøre med hvor godt man behersker diskursen, men sekundærdiskurs har gjerne smalere anvendelsesområde og tilhører en annen kontekst.
} 


\section{G. Ulland, M. Røskeland and R. Herheim}

En ytring kan aldri ses på som isolert eller nøytral, men innebærer alltid en respons på tidligere ytringer og forventning om mulige reaksjoner eller tilsvar (2005, s. 27). Denne posisjoneringen i alle ytringer skjer i forhold til ytringens tre aspekter: et emne eller innhold (referanse), talerens, det vil si skriverens, forhold til emnet (ekspressivitet), og mottaker og formål (adressivitet). Disse aspektene er ikke klart atskilte, men er integrert i hverandre og i det Bakhtin kaller ytringskonteksten. Ytringen viser således hvordan den som ytrer seg, i vårt tilfelle eleven, posisjonerer seg (selv) gjennom måter å uttrykke seg på om emnet som inngår i en kontekst (for eksempel fagets diskurser, skolen, den konkrete skrivesituasjonen osv.) og i forhold til tenkte mottakere og reaksjoner, altså det Bakthin kaller ytringens adressivitet (2005, s. 39). Hver ytring kan dermed inneholde en gienklang av mange ulike stemmer i en flerstemmighet eller "polyfoni» (Bakhtin, 1984) som vi ikke fullt ut kan overskue. I vår analyse anvender vi Bakhtins innsikter om ytringer for å si noe om hvordan elevene posisjonerer seg gjennom elevtekstene. I vårt materiale er emnet i vid forstand matematikkfaget, og elevtekstene kan dermed fortelle noe om hvordan elevene posisjonerer seg i forhold til faget. Med andre ord virker konteksten inn på elevenes tolking av skriveoppdraget, og vi kan si at oppdraget både har elementer av tvungen posisjonering, der skriveoppgaven styrer skriverens valg, og valgfri posisjonering, der elevene blant annet selv kan velge mottaker, språk, skrivemåte og modaliteter (jfr. Otnes, 2015, s. 245). Språk og fremstilling vil være preget av hvilken mottaker de har orientert seg mot - eller hvilken diskurs ytringen forholder seg til. Dette vil vi se nærmere på i analysen av tekstene.

\section{Særtrekk ved matematiske fagtekster}

Fagspesifikk lesing og skriving er sentrale komponenter i arbeidet med alle fag, men det hevdes ofte at det er særlig viktig i matematikk (Hoem, Skaftun, Solheim \& Uppstad, 2014; Adu-Gyamfi, Bossé \& Faulconer, 2010). Nedenfor vil vi ta for oss noen særtrekk ved matematiske fagtekster og språk for å tydeliggjøre hva vi ser etter i elevtekstene når vi undersøker hva elevene vektlegger når de løser oppgaven, og om, og i tilfelle hvordan, elevene bruker matematisk fagspråk når de løser oppgaven. Det handler altså primært om hvordan elevene skriver for å lære i matematikk, men det er også relevant å se om denne skrivingen forholder seg til en matematisk fagdiskurs. Deretter vil vi si noe om hva vi vet om hvordan skriving i matematikk praktiseres i norsk skole.

Et første særtrekk er at matematikktekster inneholder mange fagbegreper med en ganske presis betydning. En kompliserende faktor er at mange av matematikkfagets ord og begreper også brukes i hverdagsspråket, men da med en videre og mer generell betydning. Eksempler på slike ord er figur, posisjon, likning, funksjon og faktor. Ordet «faktor» er for eksempel brukt på en generell måte for et par setninger siden. Et annet eksempel er ordet sum, som i matematikken er resultatet av addisjon. Når man i dagligspråk «oppsummerer» eller snakker om "summen av» noe, for eksempel en rekke argumenter, er det ikke en like entydig forestilling om summering som ligger bak, siden ordet kan brukes både om referat, oppramsing av hovedpoeng og konklusion. 
Språkforskeren Martin (1998a) sier at det tekniske språket i realfagtekster «både komprimerer og endrer egenskapene til de hverdagslige ordene» (s. 299). Alle lærere må kunne oversette det komprimerte og tekniske språket til noe som gir mening og som relaterer seg til det elever kan, særlig når de skal forklare noe for de som ikke er innenfor faget eller som ikke forstår ordene. Martin understreker likevel at det er nødvendig at elevene lærer fagets språk og ikke bare oversettelser til et mer upresist hverdagsspråk. Den som har god forståelse, kan også kommunisere denne mer presist ved hjelp av fagbegreper enn ved hjelp av mindre presise hverdagsord som trenger tilleggsforklaring.

Det andre særtrekket handler om multimodalitet. Et raskt blikk på en lærebok i matematikk er nok til å se at det ikke er tilstrekkelig å kunne avkode alle ordene for å forstå det som står der. I tillegg til ord inneholder tekstene tall og andre symboler, figurer, formler, grafer, tabeller, illustrasjoner m.m. I Doerr og Chandler-Olcott (2009) sin studie blir nettopp det at elever inkluderer tegninger og figurer i sine matematiske tekster trukket fram som et kjennetegn på god matematikkskriving. Matematikktekster er med andre ord multimodale og krever forståelse av ulike tegnsystemer. Dette understrekes også av Maagerø og Skjelbred (2010), som skriver at "[f]agtradisjonen i matematikk medfører helt klart en høy grad av multimodalitet» (s. 34). I matematikkdidaktikk brukes gjerne betegnelsen representasjoner om det en i norskfaget kaller modaliteter (f.eks. bilde, tekst og visualiseringer med ulike figurer osv.), selv om begrepene brukes litt ulikt. I en multimodal tekst vil flere modaliteter sammen skape en helhetlig mening. Når det samme innholdet uttrykkes i ulike modaliteter, kan man i matematikkfaget si at representasjonene er ulike uttrykk for den samme matematiske sammenhengen. Modalitetene i en tekst kan ha lik funksjonell tyngde, det vil si at de formidler lik mengde informasjon i den multimodale teksten (Kress, 2003, s. 46), eller noen kan ha stor funksjonell tyngde, mens andre har liten.

Det er bred enighet blant matematikkdidaktikere om at god matematikkkompetanse viser seg ved at eleven kan uttrykke sin forståelse giennom ulike representasjoner, både abstrakte og konkrete, og overganger mellom disse (Enge \& Iversen, 2010, s. 146; Johnsen-Høines, 2006, s. 81; Enge \& Valenta, 2011; Kilpatrick, Swafford \& Findell, 2001). Det vil si at en matematisk sammenheng kan representeres på ulike måter, slik for eksempel en tallmengde kan uttrykkes både med å skrive tallet 5, vise fem fingre, tegne fem gienstander eller sette ring rundt fem av ti pinner.

Et tredje særtrekk ved matematiske tekster gjelder teksttyper, struktur og arbeidsmåter. Betegnelsen teksttype brukes her i tråd med allmenn tekstlingvistikk om «grunnleggjande måtar å organisere tekst på» (Breivega, 2018, s. 29) som går på tvers av sjangrer, for eksempel beskrive, fortelle, forklare og grunngi. Ofte blir teksttype brukt synonymt med «skrivemåte» (Iversen \& Otnes, 2016, s.77). Argumentasjon og logisk resonnement er helt essensielt i matematikken. «Det ligger i matematikkens natur at en alltid skal kunne argumentere for en fremgangsmåte/strategi», skriver Enge og Valenta (2011, s. 27). En god fremgangsmåte kjennetegnes ifølge Enge og Valenta av at den kan generaliseres til å gjelde alle problemer eller oppgaver av samme type. Samtidig bør den kunne konkretiseres og knyttes til hverdagslige situasjoner. 


\section{G. Ulland, M. Røskeland and R. Herheim}

Matematiske fagtekster inneholder altså resonnement og argumentasjon, men også beskrivelse av både konkrete og generelle fremgangsmåter og oppsett, definisjoner og eksempler. Slike beskrivelser inngår gjerne i matematiske forklaringer. I vårt materiale gir læreren elevene instruksen «forklar». Å forklare kan defineres som en skrivemåte der skriveren klargjør noe slik at det blir forstått, blant annet ved å peke på elementene $\mathrm{i}$ en prosess eller fremgangsmåte. En forklarende skrivemåte plasserer fenomener etter hverandre i temporale og/eller kausale relasjoner (Maagerø \& Skjelbred, 2010, s. 112). A forklare blir løftet frem som et sentralt element i elevers matematiske skriving (Meaney, 2012; Morgan, 1998) og i det naturvitenskapelige feltet generelt (Maagerø \& Skjelbred, 2010). Flere forskere har derimot pekt på at matematikk er et fag der elevene i liten grad forklarer til hverandre (Grønmo, Onstad \& Pedersen, 2010; Vavik m.fl., 2010). Vektleggingen av forklaringer står i kontrast til fokuset på svar og det å regne mange oppgaver, det Mellin-Olsen (1991) kalte oppgavediskursen. Vekten på argumentasjon, resonnement og generalisering, sammen med utstrakt bruk av matematiske symboler og spesialiserte begreper, kan giøre matematiske fagtekster meget informasjonstette.

\section{Skriving i matematikk i praksis}

Hvordan arbeides det med skriving i matematikk i norske klasserom, og hva anses som viktig? Det legges stor vekt på hvordan algoritmer skal settes opp (Herheim, 2016). Når det gjelder vurdering av skriftlige innleveringer i matematikk, viser våre observasjoner fra en mengde skoler i forbindelse med satsingen Ungdomstrinn $i$ utvikling at oppsett og orden er svært viktig, i tillegg til korrekt svar og fremgangsmåte. Med fremgangsmåte menes blant annet at elevene kjenner og kan anvende bestemte huskeregler og formler (jf. Herheim, 2016). Innen skriveteori skilles det ofte mellom produktskriving og refleksjonsskriving, der det første er skriving av tekst som skal presenteres for andre som et produkt. I kontrast til slik skriving står skriving underveis, som kan være skriving for å lære, for å tenke eller for å huske. En slik refleksjonsskriving kalles også innoverrettet skriving, det vil si at den inneholder selvrefleksjon og en tydelig jeg-stemme, og at det er elevens betraktninger, overveielser, stemning og tanker som er i fokus. Et tilsvarende begrepspar, presentasjonsskriving og tenkeskriving, er introdusert av Dysthe, Hertzberg \& Hoel (2000). Både Opsal (2013), O'Halloran (2004) og Adu-Gyamfi m.fl. (2010) hevder at det brukes mer produktskriving (blant annet for å dokumentere forståelse) enn refleksjonsskriving og skriving for å lære i matematikk.

Men dette er ikke hele bildet. Mye skriving i matematikk består i å notere og kladde. Alt det som ikke er hoderegning, kalles gjerne regning på papir (Nortvedt, 2013, s. 28). Dette er med andre ord matematikkens mest utbredte form for tenkeskriving i betydningen skriving som støtte for tanken, primært skrevet for å leses av skriveren selv. Det er ofte nødvendig å notere for å synliggiøre tanker ved utregning i matematikk, fordi slik skriving avlaster arbeidsminnet, altså den minnefunksjonen som brukes for å holde noe fremme i bevisstheten underveis i et arbeid (Mossige, Skaathun 
\& Røskeland, 2007; Kellogg, 1996). Slik skriving undervises det i, siden læreren er opptatt av å vise hvordan utregninger følger bestemte regler for oppsett og orden, og slik at både utregningsmåte og løsning kommer klart frem (jf. Herheim, 2016). Men det som skjer av forsøk, prøving og feiling på veien fram mot riktig fremgangsmåte og løsning, blir ikke like mye vektlagt. Dette blir eksemplifisert i vårt materiale.

\section{Materiale, kontekst og metode}

Materialet vårt består av 14 elevtekster fra 7. trinn og 14 elevtekster fra 10. trinn der alle elevene er bedt om å løse den samme regneoppgaven og forklare hvordan de tenker når de løser den. Elevene produserte tekstene i en matematikktime i eget klasserom, og oppgaven ble laget og introdusert av matematikklæreren i en ordinær matematikktime. De to trinnene har samme matematikklærer. Elevene på 7. trinn har hatt denne læreren i flere år, mens 10. trinn bare har hatt henne på 10. trinn. Begge elevgruppene er vant til å få oppgaver der de utfordres til å tenkeskrive eller begrunne det de arbeider med. Målet for en slik matematikkpraksis er ifølge læreren at elevene skal ha et bevisst forhold til hva de mener svaret blir før de starter på selve utregningen. Denne bevisstheten utvikles ved å for eksempel be elevene begrunne svaret sitt eller sette ord på tenkingen sin slik det er gjort i eksempelmaterialet vi tar for oss. Både 7. trinnselevene og 10. trinnselevene tok fatt på den aktuelle oppgaven med stort alvor. Elevenes lærer forteller at elevene stort sett alltid gjør det, og hun begrunner denne erfaringen med at elevene aldri får for mange oppgaver å arbeide med, og at elevene dermed stoler på at oppgavene de får er verdt å bruke tid på. Kvistad og Smemo støtter erfaringen om at elever er svært lojale overfor skriveoppdrag de får presentert (2015, s. 221).

Elevene i begge gruppene visste at tekstene skulle samles inn og leses av læreren, og de var klar over at materialet kunne bli videreformidlet. De visste også at besvarelsene ikke skulle vurderes eller gis tilbakemelding på. Elevene fikk ingen andre føringer enn instruksene som er gitt på arket:

\section{Henriette kjøpte tre par sokker og fire T-skjorter. T-skjortene kostet 79 kroner per stykk. Til sammen betalte hun 364 kroner. Hva koster et par sokker?}

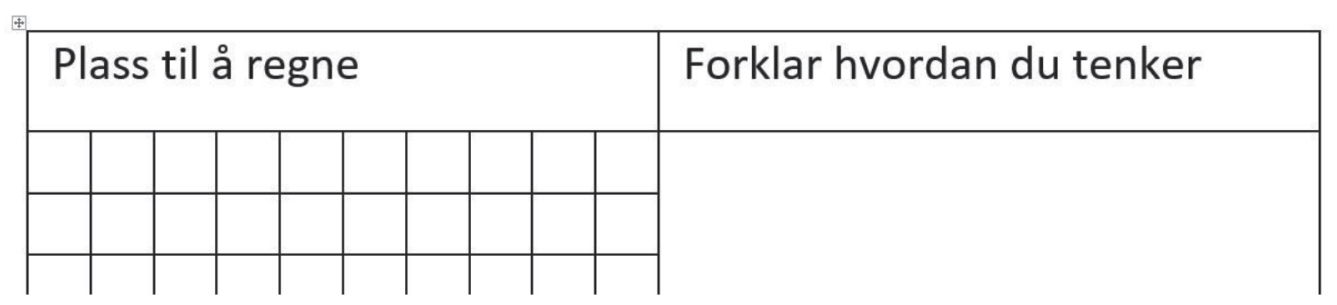

Figur 1. Oppgaven slik den ble presentert for elevene. 


\section{G. Ulland, M. Røskeland and R. Herheim}

Selve regneoppgaven er praktisk og hentet fra en hverdagslig situasjon. Den er lukket, og den har lite slingringsmonn. Oppgaven er formulert som en tekstoppgave der elevene med utgangspunkt i teksten må finne ut hvordan de skal løse oppgaven. Av figur 1 ser vi at kolonnen med plass til å regne har ruter, mens kolonnen der elevene skal forklare hvordan de tenker, verken har ruter eller linjer. Med formuleringen «forklar hvordan du tenker» bes elevene om å giøre greie for sin fremgangsmåte. Ved å bruke verbet «forklar» er elevene først og fremst invitert til å beskrive og systematisere hvordan de tenker eller går frem når de løser oppgaven. Andre verb, som «argumenter for» eller «reflekter over», ville antakeligvis gitt elevene en annen inngang til skriveoppdraget. Likevel var intensionen at ordet «tenker» skulle generere elevtekster som inneholder refleksjon, for eksempel ved å veie ulike fremgangsmåter opp mot hverandre eller ved å la egne tanker om prosessen komme eksplisitt frem i det skriftlige arbeidet. Vi kan si det slik at vi gjennom oppgaveformuleringen bidrar med å posisjonere elevene $i$ tekstene de skriver (Otnes, 2015). I denne oppgaveformuleringen blir elevene bedt om å posisjonere seg som seg selv, men også som fageksperter. Særlig når det gjelder å forklare egen fremgangsmåte, er elevene eksperter. At ordet «du» er brukt, kan forstås slik at den enkelte elevs tanker er viktige, og at vi ønsker at elevens egne valg og synspunkter skal komme frem i teksten.

Det er verdt å dvele ved påvirkningen som kan ligge i oppgaveformuleringen. Kolonnenes ulike bakgrunner (henholdsvis ruter og blank) gir elevene signaler om at det forventes noe annet fra dem når vi ber dem regne enn når vi ber dem forklare hvordan de tenker. Dette kan ha vært førende for elevenes svar, siden de fleste overveiende har skrevet matematiske symboler $\mathrm{i}$ den venstre kolonnen og verbalspråk i den høyre. Et annet spørsmål vi kan stille oss, er om elevene ville ha formulert seg annerledes om kolonnen der elevene blir bedt om å forklare hvordan de tenker hadde kommet til venstre for kolonnen med ruter og plass til å regne, i og med at leseretningen normalt går fra venstre til høyre. Ved å skille de to instruksene «å regne ut» og «å tenke» har vi ikke helt tatt høyde for at elevene faktisk kan vise hvordan de tenker gjennom selve utregningen. Vi ser altså at både oppgavetekst og den samlede oppgaveutformingen kan være styrende for hvordan elevene oppfatter hva de skal giøre. Imidlertid vil konteksten alltid påvirke ytringen, som nevnt tidligere i denne artikkelen. Vi vil derfor likevel argumentere for at materialet vårt gir innsikt i hvordan elevene uttrykker matematikkforståelse skriftlig og posisjonerer seg gjennom bruk av matematisk fagspråk og visualisering.

\section{Fremgangsmåte ved analyse av materialet}

I våre analyser tar vi for oss elevenes tekster $\mathrm{i}$ begge kolonnene, altså både utregningen og forklaringen i høyre kolonne. Vi har sett på hvordan elevene setter opp regnestykkene, hva de gjør først og sist, hvilke tall de velger å bruke og hvordan og hva de markerer og ikke markerer. Slik får vi grunnlag for å si noe om elevenes matematiske forståelse og språk. Tilsvarende, ved å gå inn i detaljer i elevenes 
verbaltekst og se på hvilke ord de bruker, hvordan de setter sammen argumenter, hvilke modaliteter som tas i bruk og presisjonsnivået i elevtekstene, får vi ytterligere grunnlag for å si noe om elevens matematiske forståelse og hvordan skriving i faget kan utvikle forståelsen. Her legger vi til grunn at det å mestre fagets arbeidsmåter, sjangrer, begreper og praksiser, altså det vi kaller fagets diskurs (Gee, 2012; Martin, 1998a), er en viktig del av det å lære et fag, slik vi har gjort greie for ovenfor, og at disse faktorene vanligvis spiller med i matematikkdidaktikeres vurdering av elevens matematikkompetanse. I analysen undersøker vi også hvordan elevene posisjonerer seg, med utgangspunkt i en forståelse av elevtekstene som ytringer, ifølge Bakhtin (2005), som innebærer ulike former for posisjonering, slik vi har gjort greie for $\mathrm{i}$ teoridelen. Vi studerer følgelig hvordan elevene gjennom språk og ulike modaliteter posisjonerer seg i forhold til emnet, altså matematikkfaget representert ved oppgaven, $\mathrm{i}$ forhold til mottakeren og situasjonen og hvordan de selv fremstår. Elevene er gitt fiktive navn $\mathrm{i}$ analysene.

\section{Analyser av elevtekster: Posisjonering og multimodalitet}

Å forstå en tekstoppgave vil ifølge Nortvedt (2008) innebære å danne seg en mental modell av oppgavens problem slik det er formulert i teksten. Elevens mentale matematiske modell kan samsvare med den intenderte oppgaven, men det forutsetter at elevene har forstått teksten i oppgaven på riktig måte. I vårt materiale har 26 av 28 forstått tekstoppgaven, og de fleste elevene løser den i en trestegs regneoperasjon. De regner først ut hva fire t-skjorter koster $(79 \cdot 4=316)$, og deretter trekker de dette beløpet fra totalsummen (364-316), for så å dele det gjenstående beløpet på tre $(48 \div 3=16)$. Det varierer i hvilken grad elevene viser hele utregningen på arket og hvordan de setter opp regnestykket. Det er også stor variasjon i hva elevene skriver i høyre kolonne under "Forklar hvordan du tenker». Dette gjelder både hvorvidt de bruker matematisk fagspråk eller ikke, og bruk av ulike modaliteter.

I den følgende analysen vil vi presentere våre tre tydeligste funn. Først viser vi eksempler på hvordan elevene posisjonerer seg som skrivere i matematikk ved hjelp av både verbalspråk og utregningsmåte. Her studerer vi i hvilken grad elevene anvender fagets begreper og argumentasjons- og skrivemåter når dette ikke eksplisitt er etterspurt i skriveoppdraget. Deretter viser vi hvordan elevene bruker ulike modaliteter i tekstene sine, med særlig vekt på visualisering. Til slutt drøfter vi hvordan elevene har tolket oppdraget "forklar hvordan du tenker». Både utregning og forklaring med verbaltekst gir informasjon om hvordan elevene går frem, men verbalteksten sier også noe om hvordan de forklarer fremgangsmåten. Vi legger ikke vekt på aldersforskjell, men ser materialet samlet som eksempler på hva både elever og lærere kan få ut av denne typen skriving i matematikk.

\section{Å posisjonere seg matematikkfaglig gjennom språk og forklaringsmåte}

Harald er vårt første eksempel. Han skriver: «Jeg finner først produktet av 79 multiplisert med 4, da finner jeg hvor mye 4 t-skjorter koster. Differansen mellom produktet 
og summen hun betalte, er hvor mye de tre parene sokker kostet. Ved å dividere dette på 3, finner jeg ut hvor mye et par koster.»

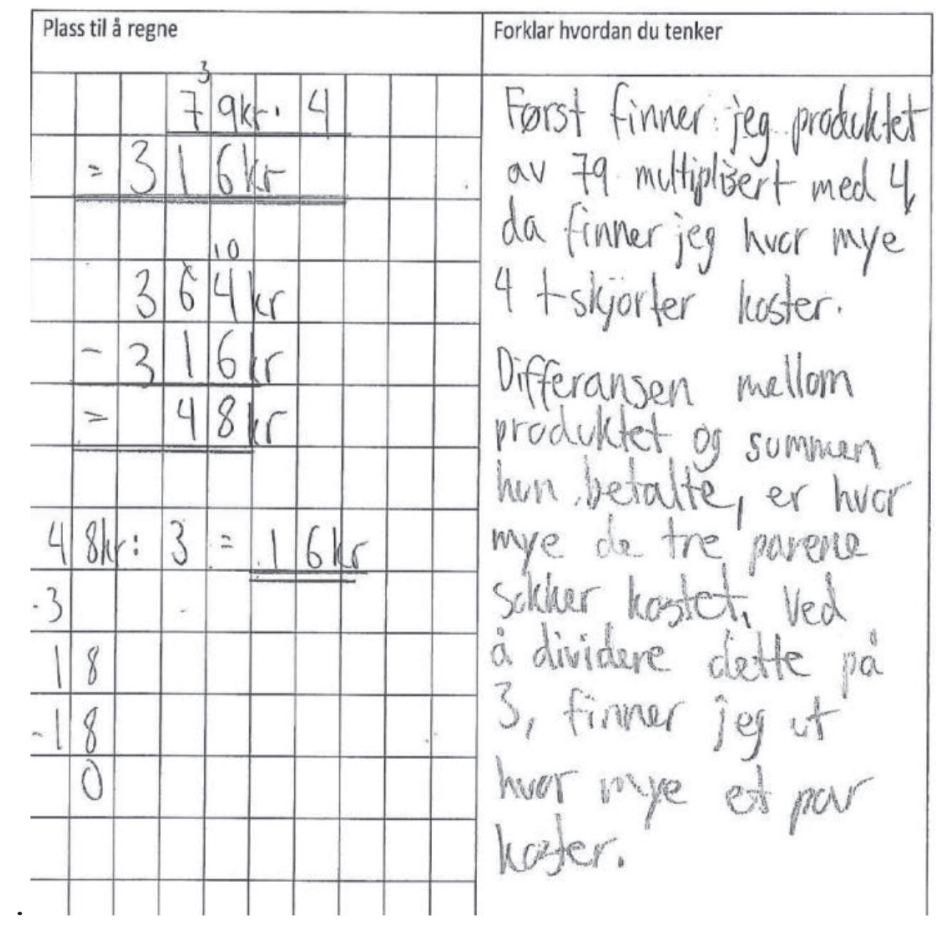

Figur 2. Harald, 10. trinn.

Haralds oppsett av regnestykket er tredelt, der han bruker tre standardalgoritmer: først multiplikasjon, så subtraksjon og til sist divisjon. Dette er representativt for det flertallet av elevene har gjort. Ved å systematisere slik at han slipper å huske tallene han kommer fram til i hvert steg i utregningen, fungerer nedskrivingen som avlasting av arbeidsminnet. Språket i høyre kolonne skiller seg imidlertid ut. Det er presist og kompakt og inneholder mange begreper som ligger nærmere en fagdiskurs enn en hverdagsdiskurs, for eksempel multiplisert, differansen, produktet og summen, og eleven bruker disse begrepene korrekt. Dette viser at språket hans har kommet langt på vei mot det Gees kaller en sekundærdiskurs. Dessuten ser vi at ord som «først» og «da» synliggjør rekkefølgen, og formuleringer som «ved å dividere (...) finner jeg ut» viser også hvordan eleven resonnerer logisk for å finne svaret.

Det matematiske fagspråket Harald har brukt i forklaringsteksten, er først og fremst tilgjengelig for de som selv kjenner begrepene. Harald posisjonerer seg dermed som matematikkfaglig skriver, og mottakeren er først og fremst læreren. Formålet kan være å vise at han behersker matematisk språk. Dersom eleven ønsker å imponere, er ikke selve utregningen egnet til det. Derimot vil bruk av fagbegreper i forklaringen kunne fungere som tegn på høy matematisk kompetanse (jf. Dagsland, 2015). Her 
ser vi altså at formål, uttrykksmåte og kontekst henger nøye sammen. Med andre ord: Eleven posisjonerer seg både i forhold til faget (emnet), konteksten og mottakeren (adressivitet) slik at han fremstår som matematikkfaglig skriver (ekspressivitet), og det er måten han uttrykker seg på i forklaringsteksten som viser dette.

En annen elev, Joar, er interessant på flere måter. Han bruker ordet «originalprisen» om det beløpet Henriette har betalt til sammen og bruker videre ordet "prisen" fem ganger i den korte verbale forklaringsteksten (se figur nr. 3). Han bruker også flere andre hverdagsspråklige vendinger som «fant jeg», "trekke fra», «stod jeg igjen med» og «delte». Eleven bruker altså i liten grad matematiske fagbegreper i svaret sitt. Eleven får dermed ikke vist om han har tilegnet seg disse begrepene. Siden fagbegreper ikke blir etterspurt eksplisitt i oppdraget, kan vi heller ikke på dette grunnlaget vurdere svaret som faglig svakere enn for eksempel Haralds. Det vi vet noe om, er hvordan han skriver i matematikk når det ikke gis spesifikke rammer for språk og begreper. Joar viser likevel en fortrolighet med fagets diskurs ved at han bruker en typisk argumentasjonsstruktur i matematikkfaget: «Først fant jeg ... så trakk jeg ... da stod jeg ... så jeg ... og fikk».

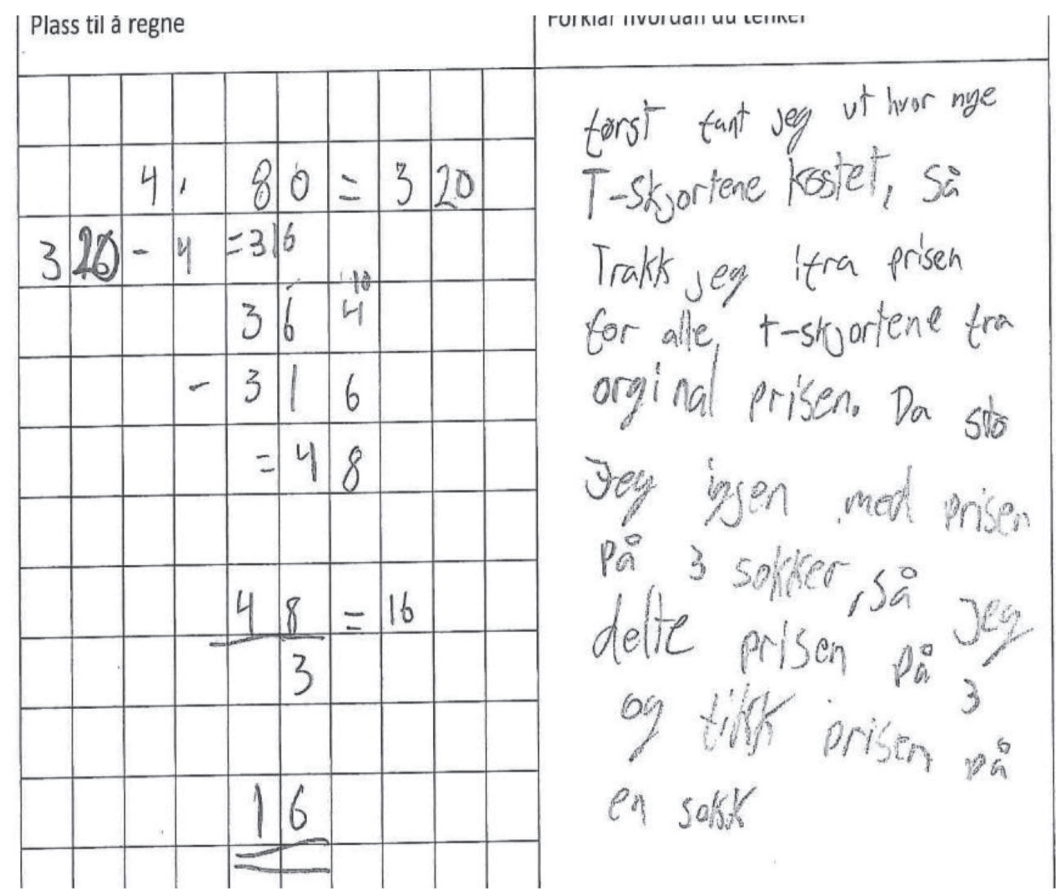

Figur 3. Joar, 10.trinn.

Utregningen viser at Joar ikke bruker vanlig oppsett for multiplikasjon. Han bruker imidlertid en forenklingsstrategi der han regner ut det første beløpet $(79 \cdot 4)$ ved å runde opp til 80 per skjorte og trekker så fra 4. Forenkling kan være en god strategi fordi den gjør oppgaven om til noe som er lettere å løse. Eleven viser med dette god tallforståelse, og han forstår det matematiske problemet godt. Ulikt de fleste andre 


\section{G. Ulland, M. Røskeland and R. Herheim}

synliggjør han også utregningsstrategien sin (forenkling), og dette kan sees på som en matematikkfaglig styrke. Her forteller dermed utregningen i venstre kolonne mer om hvordan eleven tenker enn hva verbalteksten giør. I dette oppgavesvaret posisjonerer han seg derfor mer matematikkfaglig gjennom utregningsmåten, altså gjennom hvordan han forholder seg til emnet i praksis, enn gjennom språket i forklaringsdelen. Dette gjelder også i stor grad for de to følgende elevtekstene.

\section{Å posisjonere seg matematikkfaglig gjennom utregningen}

Trine er den eneste som giør regnestykket om til en likning med en ukjent: $(4 \cdot 79)+3 x=364)$. Teksten hennes i høyre kolonne er slik: "Jeg tenker at siden jeg allerede vet hva en t-skjorte koster er det bare å finne ut hvor stor del av totalsummen 4 av de gjør opp også dele det som er igjen på hvor mange sokker hun kjøpte (3) for å finne ut hva hun betalte for et par.»

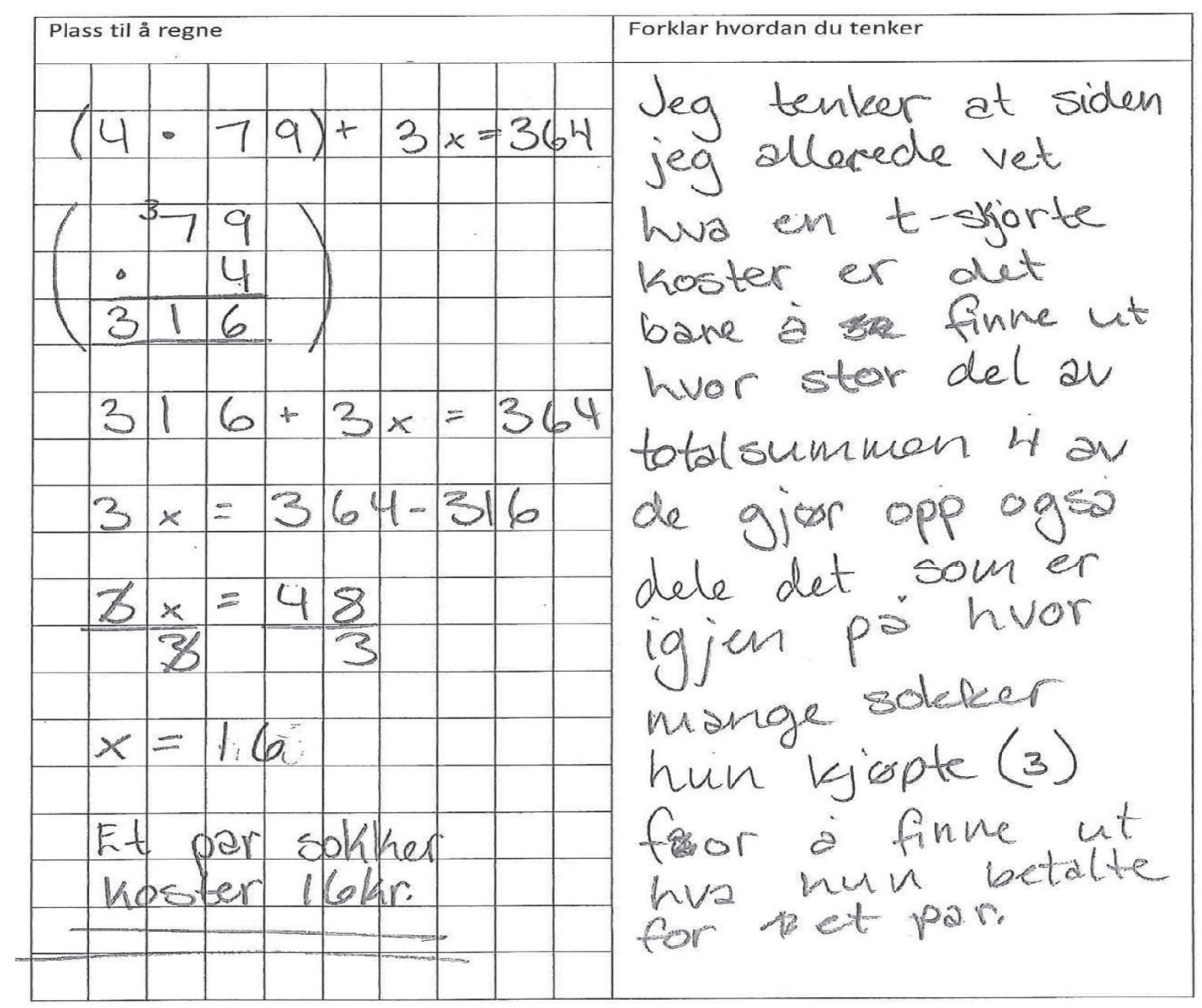

Figur 4. Trine, 10. trinn.

Trines utregningsmåte skiller seg ut ved at hun bruker algebra og generaliserer. I forklaringen i høyre kolonne er språket hennes imidlertid mindre faglig markert enn Haralds, men det betyr ikke at forståelsen er dårligere. Det er verdt å merke seg at Trine generaliserer også i den verbalspråklige forklaringen, ved at den gjelder for alle 
oppgaver av samme type, uavhengig av beløp. Hun forklarer altså ikke bare hvordan hun tenkte da hun regnet, men hvordan hun tenker om dette regnestykket og om alle regnestykker av samme type - og hvorfor.

Verbalteksten til Trine kan gjenspeile utregningsmåten, siden begge er skritt på veien mot å generalisere fra en konkret situasjon til en generell løsningsmetode på et matematisk problem. Dette samsvarer godt med krav til gode forklaringer i matematikk (jf. Enge \& Valenta, 2011, s. 27), og det tjener som grunnlag for å si at også Trine posisjonerer seg matematikkfaglig, men på en annen måte enn Harald. Hun nærmer seg matematikkfagets diskurs gjennom å generalisere, siden fagdiskurs handler like mye om prosesser, løsningsmåter og holdninger til emnet som om verbalspråk og begreper. Hun bruker også logikk fra matematikkfagets diskurs når hun skriver «siden ... er det bare ... for å finne ut». Dette er typiske språkgrep for å strukturere en matematisk logikk. Tilsvarende er vendingene "siden jeg allerede vet» og «er det bare å» tydelige eksempler på en klassisk måte å ordlegge seg på i matematikkfagets diskurs. Med begreper fra Bakhtin kan vi si at tekstens adressivitet ligger $i$ at eleven forholder seg på en markert måte til en matematisk ytringskontekst.

Det er bare én elev, Lise, som gjør utregningen som én sammensatt regneoperasjon:

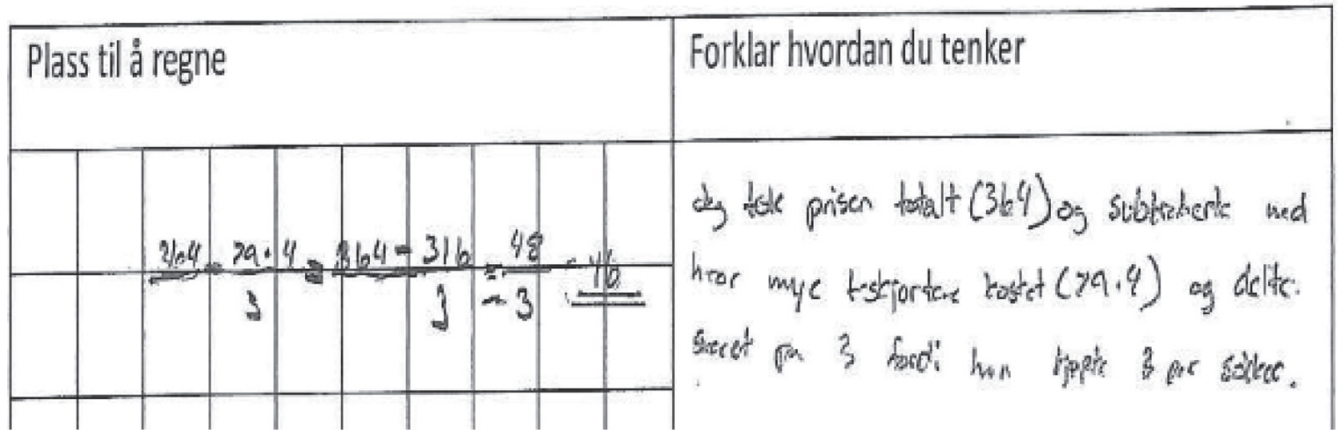

Figur 5. Lise, 10. trinn.

Utregningen er altså slik: $\frac{364-79.4}{3}=\frac{364-316}{3}=\frac{48}{3}=16$. Lises skriftlige forklaring er svært kort: «Jeg tok prisen totalt (364) og subtraherte med hvor mye t-skjortene kostet $(79 \cdot 4)$ og delte svaret på 3 fordi hun kjøpte 3 par sokker.» Teksten inneholder bare ett markert fagbegrep, subtraherte, mens hun på samme måte som Joar og Trine skriver «delte» og ikke «dividerte». Disse to ordene er likestilt når det gjelder matematisk forståelse, selv om å dele også er hverdagsspråk og kan ha flere betydninger. Også Lise beskriver først og fremst en regneoperasjon og egentlig ikke hvordan hun tenker. Hennes regneoperasjon er den mest komprimerte og matematisk avanserte, og forståelsen hennes er god. Lise viser at hun behersker aritmetiske oppsett og matematisk symbolbruk. Sammenlignet med for eksempel Harald, får hun ikke vist hvor godt hun behersker fagbegreper. Men gjennom det komprimerte og presise ved forklaringen og den tydelige matematisk-logiske strukturen «Jeg tok ... subtraherte ... hvor mye 


\section{G. Ulland, M. Røskeland and R. Herheim}

... delte ... fordi», får hun vist at hun behersker matematisk diskurs. Hun forklarer premissene og begrunner hva hun giør, og det blir særlig tydelig ved bruken av den logiske markøren «fordi». Hun posisjonerer seg med andre ord tydelig i forhold til en matematikkfaglig «ytringskontekst» der både skriveren og mottakeren behersker fagets språk og symboler.

I tekstene vi har omtalt til nå er forklaringstekstene først og fremst verbale. Videre skal vi se nærmere på elevtekster der det multimodale kommer sterkere inn.

\section{Elevtekstene som multimodale tekster}

Det er særlig på 7. trinn elevene visualiserer utregningen ved hjelp av både tegninger og modeller. Elevenes lærer har informert om at hun i flere år har lagt vekt på å konkretisere og visualisere fremgangsmåter i matematikk. Det er i tråd med at tegning blir sett som et kjennetegn på god matematisk skriving (Doerr \& Chandler-Olcott, 2009), og det kan forklare hvorfor halvparten av de 14 elevene på 7. trinn bruker tegning som strategi både i utregning og når de skal forklare hvordan de tenker. Dette viser samtidig at det læreren vektlegger i undervisningen, gjenspeiler seg i elevenes tekster.

Når vi nå skal se på hva elevene velger å visualisere, og hvordan de gjør dette, så er det tydelig at elevene stort sett tegner for å vise hva pengene (totalsummen) brukes til. I materialet er det naturlig nok flere elever som visualiserer det samme som de forklarer med verbaltekst. En slik forankring viser at de mestrer å bruke ulike modaliteter eller representasjoner for å synliggjøre sin egen forklaring og forståelse. La oss se på et eksempel der en visualisering fungerer som en oppsummering, en tilleggsforklaring, nederst på arket. Eleven redegjør for regneoperasjon og svar gjennom en komprimert tegning av 4 t-skjorter og 3 par sokker (se figur nr. 6).

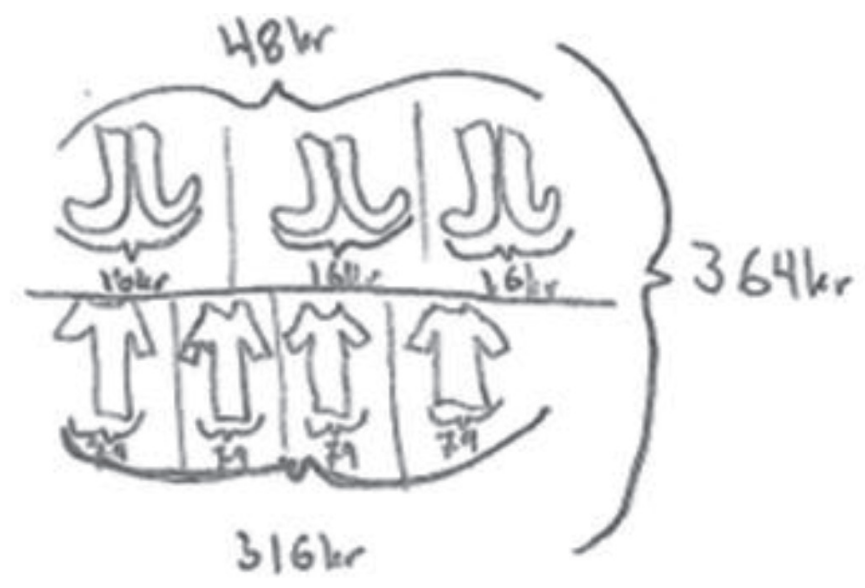

Figur 6. Vebjørn, 7. trinn.

Eleven har skrevet enkeltsummen for hvert klesplagg og markert med klamme hva sokkeparene koster til sammen, hva t-skjortene koster til sammen og hva totalsummen blir. Slik blir regnestykket mer visuelt og oversiktlig. Å kunne giøre rede for fremgangsmåte 
og svar med ulike representasjoner kan bidra til bedre forståelse enn å utelukkende bruke matematiske symboler (se f.eks. Enge og Iversen, 2010). Visualiseringen fungerer utvidende i elevteksten siden det er en tilleggsforklaring, samtidig som den konkretiserer situasjonen ved å tydeliggjøre at det her er snakk om klesplagg. Visualiseringen fungerer som dokumentasjon på at det som er skrevet i utregning og forklaring er korrekt. Andre 7. klassinger har tegnet t-skjorter der det henger tydelige prislapper på med påskriften «79 kr». Da blir den konkrete situasjonen som er utgangspunktet for regneoppgaven enda tydeligere. Tegning som representasjon og som etterligning av den konkrete situasjonen, er noe også Enge og Iversen finner eksempler på i sine analyser av elevtekster. Elevene bruker visualisering som organiseringsstrategi og samtidig som avlastning av arbeidsminnet når de setter prislapper på sokkene og t-skjortene.

En organisering av hva pengene brukes til, ser vi også i det neste eksemplet. Denne eleven viser hva pengene går til, men visualiseringen har en mer generaliserende utforming, løsrevet fra kroner, sokker og t-skjorter:

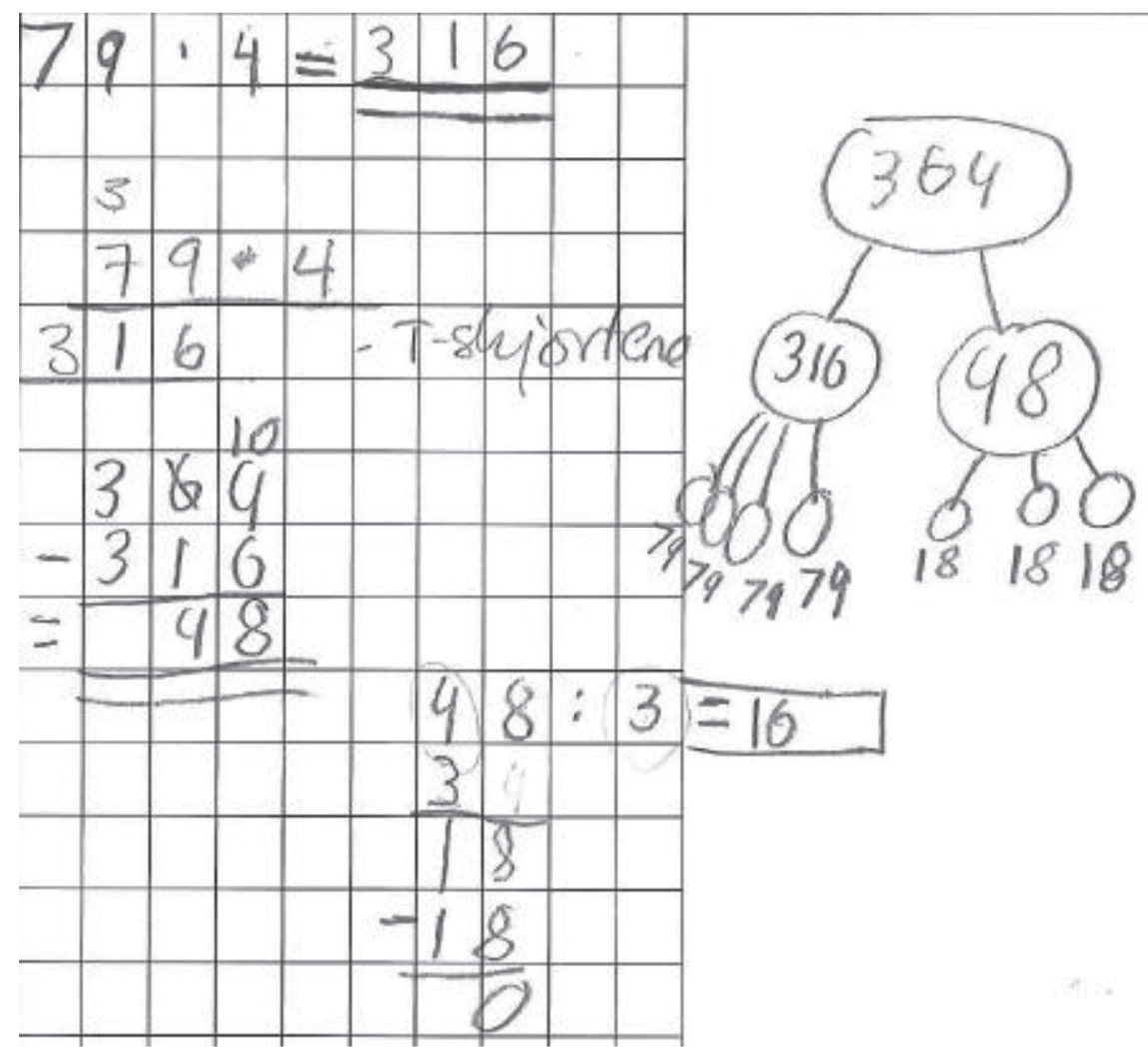

Figur 7. Kasper 7. trinn.

Både utregningen og tegningen gir en ryddig redegjørelse for hva pengene har blitt brukt til. Tegningen kan sees på som en redegjørelse for hvordan eleven tenker, i og med at den er det eneste som står i kolonnen der eleven skal forklare hvordan 


\section{G. Ulland, M. Røskeland and R. Herheim}

han tenker. Visualiseringen formidler resultatet av utregningen ved at den synliggiør hvordan eleven har delt opp helheten i tallmengder.. Å lage en slik representasjon krever god matematikkforståelse. Eleven har valgt å gi visualiseringen all funksjonell tyngde i forklaringen sin i høyre kolonne. Det er derfor sannsynlig at eleven tenker at illustrasjonen er selvforklarende, og at den står godt til utregningene han har gjort i venstre kolonne. Det gjør den også, rent bortsett fra at eleven skriver «18» i stedet for «16» (han har korrekt utregning på rutearket).

Enge og Valenta (2011) skriver at å tegne i seg selv kan fungere som argumentasjon for at en utregning er korrekt, og begge de nevnte eksemplene kan ses på som representasjonsbevis der visualiseringen kan involvere (deler av) regneoperasjonene eleven har vært gjennom for å komme frem til svaret. Dessuten kan tydeliggiøringen vise hvordan eleven posisjonerer seg ved å uttrykke sin egen tenkemåte (ekspressivitet) og i forhold til flere mottakere (lærer som verdsetter visualisering eller medelev som skal forstå regnestykket) og emne.

\section{Om å forklare og tenke}

I omtalen av oppgaveformuleringen diskuterte vi at «forklar hvordan du tenker» kan invitere til å beskrive fremgangsmåte fremfor å dele tanker og refleksjoner om prosess og resultat. Både formuleringen og plasseringen av formuleringen bidrar til at elevene bruker den høyre kolonnen til å beskrive fremgangsmåte i mye større grad enn til å reflektere eller til å innvie leseren i egne tanker. Intensjonen i denne kolonnen var at elevene skulle veie for og imot og fundere over eget resultat og dermed ha tydelige islett av det vi kan forstå som tenkeskriving (jf. Dysthe, Hertzberg \& Hoel, 2000). I og med at materialet viser at elevene i stor grad nøyer seg med å nøkternt gjøre rede for egen fremgangsmåte, bekrefter elevtekstene det Dagsland (2015, s. 201) skriver om at intenderte reflekterende skriveoppgaver ikke nødvendigvis genererer reflekterende elevtekster. En finner likevel noen refleksjonsmarkører og eksplisitte uttrykk for elevenes tanker i elevtekstene.

Elevene har en tydelig jeg-stemme når de forklarer hvordan de tenker. Refleksjonsskriving er ofte jeg-orientert og tar utgangspunkt i egne erfaringer og tanker (Bakke, 2014, s. 71). Så mange som 12 av 14 elever på 7. trinn og 13 av 14 på 10. trinn bruker «jeg» i sin forklaringstekst. I Otnes og Iversen (2016) identifiseres reflekterende skriving som skriving der eleven retter fokus mot egne tanker og eget arbeid. Verb som «tro", "tenke» og "føle» er relatert til denne skrivingen, og også våre elever bruker verbet «å tenke» når de skal forklare hvordan de tenker. Maja skriver: «Jeg tengte slik: Det er fire ...», og Alice skriver: "Jeg tenker at siden jeg allerede vet ...». I flere av tekstene er "tenke» gjentatt som om eleven understreker at han nettopp forklarer hvordan han tenker. Det kan lyde påfallende i en kort forklaringstekst, som når Simen (7. trinn) gjentar verbet «tenke» to ganger i teksten sin: «Jeg tenkte $79 \cdot 4$ og det ble 316 og siden hun brukte $364 \mathrm{kr}$ tok jeg $364-316$ som ble 48 og da tenkte jeg $48 \div 3$ som ble 16 .» På den annen side er det også naturlig å bruke "tenke», siden oppgaveformuleringen nettopp ber elevene om å forklare hvordan de tenker. 
Andrea bruker det trykksvake adverbet «jo» for å understreke noe hun oppfatter som alminnelig kjent: «Hun betalte jo $364 \mathrm{kr}$ til sammen, så da subtraherer jeg det med svaret jeg fikk i forrige stykke. Hun kjøpte jo 3 par sokker så da deler jeg mitt forrige svar på 3.» Bruken av «jo» kan også indikere at eleven prøver å uttrykke hvordan hun tenker når hun regner ut. Det vil si at «jo» brukes bekreftende, som om Andrea argumenterer til en tenkt mottaker at forklaringen og fremgangsmåten hennes er plausibel. Igjen kan vi vise til Enge og Valenta som hevder at «Det ligger i matematikkens natur at en alltid skal kunne argumentere for en fremgangsmåte/strategi» (2011, s. 27).

Å synliggjøre en førregningsstrategi eller en skrivestrategi er også en måte å vise leseren hvordan en tenker. En førregningsstrategi handler om å gjøre noen grep før en tar fatt på selve utregningen. Nortvedt skriver at elevene trekker veksler på både matematisk kompetanse og generelle lesestrategier når de løser tekstoppgaver (2013, s. 27). Flere av elevene på 7. trinn har innlemmet dette i forklaringen sin i høyre kolonne, mens noen har latt slike tenkemåter komme til syne mer implisitt. Andrea starter forklaringen sin med å påpeke sin skrivestrategi når hun skriver: "Jeg setter strek i teksten for å få fram det viktige.» Oppgaveteksten hennes viser derfor tjukke blyantstreker under det hun oppfatter som viktig i teksten:

\section{Henriette kjøpte tre par sokker og fire T-skjorter. T-skjortene kostet 79 kroner per stykk. Til sammen betalte hun 364 kroner. Hva koster et par sokker?

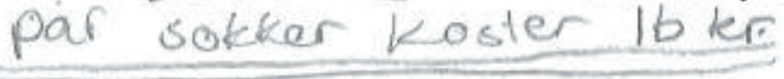

Figur 8. Andrea, 7. trinn. Førregningsstrategi.

Like under oppgaveteksten har Andrea skrevet svaret, og markert dette med to streker under. Hun bruker da et vanlig grep for å fremheve svaret som viktig. Også Enge og Iversen (2010, s. 150) viser til dette grepet, og de legger til at en innramming av svaret før selve regneoperasjonen er en visuell ressurs som synliggjør hva eleven oppfatter som viktigst å formidle.

Elevene på både 7. trinn og 10. trinn tar i bruk logiske markører som «Det betyr at» og «derfor». Slike markører viser en mottakerbevissthet og er nær knyttet opp til det å forklare en fremgangsmåte for en mottaker. Sander (10. trinn) starter sin forklaring med "Det jeg gjør er at jeg tar og finner ut ...», noe som lyder som en autentisk introduksjon til en fremgangsmåte. Det viser oss at han ønsker å innlemme mottaker i hvordan han går frem for å løse oppgaven. Det fins også andre uttrykk som understreker at elevene i høyre kolonne forklarer fremgangsmåten sin til en mottaker. «Det første jeg gjør» og «Det andre jeg gjør» eller konstruksjoner som «så gjorde jeg (...) så deler jeg» viser oss at elevene tilstreber å forklare fremgangsmåten kronologisk slik at en mottaker lett kan følge det eleven har tenkt eller gjort. 


\section{G. Ulland, M. Røskeland and R. Herheim}

Det fins altså flere ulike spor av tenkeskriving i tekstmaterialet; både jeg-stemmen, bruk av selve ordet "tenke» og synlige skrivestrategier er noen eksempler. Likevel er det slik at den høyre kolonnen i større grad brukes til å beskrive fremgangsmåte enn til å reflektere. Et slikt misforhold mellom intendert og realisert skrivehandling kan skyldes oppgavetolkning, men det kan like gjerne skyldes at oppgaveformuleringen har vært for upresis (Otnes, 2015). Ordet "forklar» har en fremtredende rolle i oppgavelyden, og dette gjenspeiles i elevtekstene i form av nøkterne beskrivelser heller enn personlige refleksjoner. I tillegg er det slik at å dele egne tanker om en regneprosess er krevende i et fag der oppgavediskursen med sterkt fokus på rett svar og å regne mange oppgaver dominerer. Den nøkterne utgreiingen om fremgangsmåte er elevenes måte å vise hvordan de tenker innenfor faget. I det de beskriver, vil de også i stor grad oppfatte hva de forstår og hva de eventuelt ikke forstår. På denne måten kan vi si at en beskrivelse av egen prosess nettopp er elevenes forklaring av hva de tenker.

\section{Oppsummering}

I dette prosjektet har vi undersøkt sammenhenger mellom skriving og forståelse av matematikk. For å få innsikt i dette har vi analysert elevtekster som svarer på et skriveoppdrag der elevene er bedt om å regne ut og forklare hvordan de tenker når de løser et regnestykke. Elevtekstene inneholder både hverdagsspråk, matematisk fagspråk og visualiseringer i tillegg til utregninger med tall. Analysen av elevtekstene viser at kombinasjon av utregning og forklarende tekst kan gi mer informasjon om elevens matematikkforståelse enn bare utregningen med tall alene, siden utregningene de fleste gjør er ganske like. Det er dermed grunnlag for å si at det å la elevene skrive om hvordan de går fram i tillegg til å løse oppgaver, kan gi læreren et bedre utgangspunkt for å veilede elevene i matematikk.

Analysene av forklaringene i høyre kolonne i elevtekstene gir informasjon om i hvilken grad elevene har tilegnet seg og bruker matematiske begreper. Dermed kan elevene få vist mer av sin matematikkompetanse, selv når regneoppgaven er så lett som her. Ord, uttrykksmåter, abstraksjoner og ulike visuelle representasjoner sier dessuten noe om formålet med skrivingen hos den enkelte eleven. Å la elevene forklare i tillegg til å regne, gjør med andre ord oppgaven mer differensiert.

Analysene viser dessuten at både forklaringsteksten og utregningen kan gi innsikt i holdninger til faget og hvordan eleven ønsker å fremstå (matematikkfaglig kompetent, flink, pliktoppfyllende, slurvete, gjør det jeg må osv.). Materialet viser likevel at elevene benytter muligheten for å posisjonere seg faglig mer gjennom forklaringsteksten enn utregningsmåten.

Det multimodale ved elevtekstene gir også et bredere innblikk i elevenes matematikkompetanse. Ulike modaliteter tilbyr ulike muligheter for elevene til å forklare hva de tenker. I elevtekstene ser vi at både verbaltekstene og tegningene kan representere elevens måte å tenke, men uttrykket er mer visuelt med tegninger enn med verbaltekst og utregning alene. Det at elevene kan uttrykke den samme 
informasjonen i ulike modaliteter eller representasjoner, viser at de ser sammenhenger mellom disse, og det er et viktig kjennetegn på faglig forståelse.

Med Bakhtins begreper kan vi si at elevene med sine ytringer posisjonerer seg i forhold til både faget matematikk, til leseren (læreren eller en tenkt mottaker som vet mindre enn eleven) og mulige måter å uttrykke seg på. Vi kan også se elevtekstene som en respons på tidligere ytringer som til dels styrer hvordan de forventer at deres egne tekster (ytringer) vil bli mottatt. Tekstene forteller derfor en god del om elevenes forståelse av faget og konteksten, i tillegg til deres forståelse av denne konkrete oppgaven. Selve oppgaveformuleringen "plass til å regne» og "forklar hvordan du tenker» har gitt elevene føringer for hvordan de har løst skriveoppdraget. Samtlige elever viser utregning der de har fått plass til å regne (venstre kolonne), mens elevene i høyre kolonne forklarer hva de har gjort eller tenkt. Det at de fleste elevene skriver i et forklarende hverdagsspråk i høyre kolonne, kan vise at de har oppfattet skriveoppdraget som uformelt, gitt i en velkjent kontekst, der den tenkte mottakeren er læreren og der de selv kan veksle mellom å være fageksperter og eksperter på hvordan de selv har tenkt og løst regneoppgaven. Det ser ut til at det å forklare hvordan en tenker for å løse oppgaven, i stor grad blir ensbetydende med å forklare hva en gjør. Dette kan ha sammenheng med det som tradisjonelt er dominerende undervisningsformer i matematikk. Flere forskere har pekt på at matematikk er et fag der elevene snakker lite sammen (jf. Grønmo m.fl., 2010; Vavik m.fl., 2010). Hvis elevene samtaler lite i et fag, og kanskje attpåtil sitter på rekke bak hverandre, så får de heller ikke aktivert et ordforråd som kan språkliggjøre egne prosesser. Da er de heller ikke vant til å skrive frem egne refleksjoner rundt valg av utregningsmåte og det ferdige resultatet. Å vektlegge skriving i matematikkfaget kan legge til rette for å sette ord på slike prosesser. Samtidig blir lærerens utforming av selve skriveoppdraget avgjørende, da hvert enkelt skriveoppdrag legger føringer for hvordan elevene forstår hva de skal gjøre, hvem de skal skrive til og hvordan de skal posisjonere seg.

Et sentralt aspekt ved matematikkopplæring er at eleven forstår og kan løse matematiske problemer. Eleven trenger fagspråket med sine ord, begreper og ordningsmåter for å uttrykke seg presist og korrekt i faget. God matematikkompetanse viser seg også i det å kunne oversette dette kompakte matematikkspråket til «sunn fornuft» og hverdagssprå $k^{2}$. Elever trenger ikke å beherske det matematiske fagspråket for å forstå matematiske forhold og operasjoner på de lave klassetrinnene, men etter hvert som nivået blir høyere, vil det bli vanskeligere for dem å lese og produsere matematiske tekster dersom de ikke har arbeidet med å utvikle sitt matematiske fagspråk. Trolig gjør vi i det lange løp elevene en bjørnetjeneste ved å skjerme dem for vanskelige nye ord og teksttyper som skiller seg fra hverdagsspråket. Da er det viktig at den diskursen de føres inn i, blir så godt integrert at den kan brukes til å tenke, forstå og reflektere med.

Våre analyser illustrerer hvor mye det er å hente ved å gi plass til flere typer skriving i matematikk. Å skrive for å lære, i tillegg til å skrive for å dokumentere og å regne på

\footnotetext{
${ }^{2}$ Dette kan også kalles «lingvistisk oversettelse», til forskjell fra «symbolsk skriving» som betegner matematisk språk (Jakobsson-Åhl, 2011, s 102).
} 
papir, kan med fordel gis mer plass i matematikkfaget. Elevene må få øve på å bruke fagets språk og begreper og å uttrykke seg (skriftlig) gjennom ulike representasjoner.

\section{Takk}

Takk til Inger Elin Lilland for verdifulle innspill til teksten, og takk til læreren og elevene som lot oss få tilgang til elevenes tekster.

\section{Litteraturliste}

Adu-Gyamfi, K., Bossé, M. J. \& Faulconer, J. (2010). Assessing understanding through reading and writing in mathematics. International fournal for Mathematics Teaching and Learning, 11(5), 1-22.

Albert, L. (2000). Outside-in - inside-out: Seventh grade students' mathematical thought processes. Educational Studies in Mathematics, 41(2), 109-141.

Bakhtin, M. (1984). Problems of Dostoevsky's poetics (redigert og oversatt av C. Emerson). Minneapolis MN: University of Minnesota Press.

Bakhtin, M. (2005). Spørsmålet om talegenrane. Oslo: Ariadne.

Bakke, J. O. (2014). А̊ «late tanker» med penn og tastatur. I K. Kverndokken (Red.), 101 Skrivegrep (s. 56-75). Bergen: Fagbokforlaget/LNU.

Bakke, J. O. \& Skovholt, K. (2015). «Å forestille seg betyr å bruke fantasien til å tenke på noe som ikke fins» Introduksjon av skriveoppgaver på 7. trinn. I H. Otnes (Red.), A invitere elever til skriving. Ulike perspektiver på skriveoppgaver (s. 139-158). Bergen: LNU/Fagbokforlaget.

Berge, K. L. (2007). Grunnleggende om grunnleggende ferdigheter. I H. Hølleland (Red.), På vei mot Kunnskapsløftet (s. 228-250). Oslo: Universitetsforlaget.

Breivega, K.M.R. (2018). Tekstperspektivet i skriveopplæringa. I K. Breivega og M. Selås (Red.), Skriveboka. Innføring $i$ skriveopplcering. Oslo: Det Norske Samlaget.

Dagsland, S. (2015). Om relasjonen skrivehandling - skriveoppgaver - elevtekst. Utfordringer ved antatt reflekterende elevtekster. I H. Otnes (Red.), Å invitere elever til skriving. Ulike perspektiver på skriveoppgaver (s. 201-220). Bergen: LNU/Fagbokforlaget.

Doerr, H. M. \& Chandler-Olcott, K. (2009). Negotiating the literacy demands of Standards-Based curriculum materials: A site for teachers' learning. I J. Remillard, B. A. Herbel-Eisenmann \& G. M. Lloyd (Red.), Mathematics teachers at work: Connecting curriculum materials and classroom instruction (s. 282-301). New York: Routledge.

Dysthe, O., Hertzberg, F. \& Hoel, T. L. (2000). Å skrive for å lare. Skriving $i$ høyere utdanning. Oslo: Universitetsforlaget.

Enge, O. \& Iversen, H. M. (2010). Et norsk- og matematikkfaglig blikk på matematiske tekster i en femteklasse. I J. Smidt (Red.), Skriving $i$ alle fag - innsyn og utspill (s. 143-162). Trondheim: Tapir Akademisk Forlag.

Enge, O. \&Valenta, A. (2011). Argumentasjon og regnestrategier. Tangenten-tidsskrift for matematikkundervisning, 22(4). 27-32.

Gee, J. P. (2012). Social Linguistics and Literacies. Ideology in Discourse. London, N.Y.: RoutledgeFalmer.

Gibson, J. J. (1978). The ecological approach to visual perception of pictures. Leonardo, 11, 227-235.

Grønmo, L. S., Onstad, T. \& Pedersen, I. F. (2010). Matematikk i motvind. TIMSS Advanced 2008 i videregående skole. Oslo: Unipub.

Helenius, O. (2017). Språket lyfter de matematiske begreppen. Origo - för lärare $i$ matematik, teknik och naturvetenskapliga ämnen. Hentet fra http://tidningenorigo.se/spraket-lyfter-de-matematiska-begreppen/

Herheim, R. (2016). Matematikk som magi - hugsereglar og konsekvensar. I T. Rangnes \& H. Alrø (Red.), Matematikklcering for framtida. Festskrift til Marit fohnsen-Høines (s. 129-146). Bergen: Caspar Forlag.

Herheim, R. \& Johnsen-Høines, M. (2016). Matematikksamtaler. Undervisning og lering - analytiske perspektiv. Bergen: Caspar Forlag.

Hoem, F. T., Skaftun, A, Solheim, O. J. \& Uppstad, P. H. (2014). Lesing i matematikk. I A. Skaftun, O. J. Solheim \& P. H. Uppstad (Red.), Leseboka. Leseopplcering $i$ alle fag på ungdomstrinnet (s. 87-112). Oslo: Cappelen-Damm.

Jakobsson-Åhl, T. ( 2011). Hvordan forklarer elevene sin egen oppgaveløsning i matematikk? I K. H. Flyum \& F. Hertzberg (Red.), Skriv $i$ alle fag! Argumentasjon og kildebruk $i$ videregående skole (s. 99-113). Oslo: Universitetsforlaget. 


\section{Språk teller! Om hvordan elever løser, tenker rundt og skriver om et regnestykke}

Iversen, H. M. \& Otnes, H. (2016). Å lare à skrive. Tekstkompetanse $i$ norskfagets skriveopplaring. Oslo: Universitetsforlaget.

Johansen, A. (2012). Skrivemåte og metode. I A. Johansen (Red.), Kunnskapens språk. Skrivearbeid som forskningsmetode. Oslo: Scandinavian Academic Press.

Johansen, A. (2014). Tenketeknologi. Språknytt, 42(4). Hentet fra http://www.sprakradet.no/Vi-og-vart/ Publikasjoner/Spraaknytt/spraknytt-2014/Spraknytt-42014/Tenketeknologi/

Johnsen-Høines, M. (2002). Fleksible språkrom. Matematikklcering som tekstutvikling (Doktoravhandling). Bergen: Universitetet i Bergen.

Johnsen-Høines, M. (2006). Begynneropplceringen: Fagdidaktikk for barnetrinnets matematikkundervisning. Bergen: Caspar Forlag AS.

Johnsen-Høines, M. \& Alrø, H. (2013). Leringssamtalen i matematikkfagets praksis. Bok II. Bergen: Caspar Forlag AS.

Karlsen, I. \& Maagerø, E. (2009). Figuren som multimodal utfordring i lesing av matematikktekster. I S. V. Knudsen, D. Skjelbred \& B. Aamotsbakken (Red.), Lys på lesing. Lesing av fagtekster $i$ skolen (s. 251-270). Oslo: Novus Forlag.

Kellogg, R. T. (1996). A model of working memory in writing. I C. M. Levy \& S. Ransdell (Red.), The Science of Writing (s. 57-72). Mahwah, NJ: Lawrence Erbaum Associates.

Kilpatrick, J., Swafford, J. \& Findell, B. (2001). Adding it up. Helping children learn Mathematics. Washington D.C.: National Academic Press.

Kress, G. (2003). Literacy in the New Media Age. London: Routledge.

Kvistad, A. H. \& Smemo, J. (2015). Den gode skriveoppgaven? En studie av fellestrekk ved vellykkede skriveoppgaver fra Normprosjektet. I H. Otnes (Red.), A invitere elever til skriving. Ulike perspektiver på skriveoppgaver (s. 221-242). Bergen: LNU/Fagbokforlaget.

Martin, J. R. (1998a). Skriving i naturfaget: om å lære å behandle tekst som teknologi. I K. L. Berge, P. Coppock \& E. Maagerø (Red.), À skape mening med språk. En samling artikler av M. A. K. Halliday, R. Hasan og f. R. Martin (s. 292-332). Oslo: LNU/Cappelen Damm Forlag.

Martin, J. R. (1998b). Livet som substantiv: en undersøkelse av naturvitenskapens og humanioras univers. I K. L. Berge, P. Coppock \& E. Maagerø (Red.), Å skape mening med språk. En samling artikler av M. A. K. Halliday, R. Hasan og F. R. Martin (s. 333-386). Oslo: LNU/Cappelen Damm Forlag.

Meaney, T. (2012). Writing to help students think mathematically. I T. Meaney, T. Trinick \& U. Fairhall (Red.), Collaborating to meet language challenges in indigenous mathematical classrooms (s. 99-120). New York: Springer.

Misfeldt, M. (2006). Mathematical writing (Doktoravhandling). København: The Danish University of Education.

Morgan, C. (1998). Writing mathematically: The discourse of investigation. London: Falmer Press.

Mossige, M., Skaathun, A., Røskeland, M. (2007). Fleire vegar mot mål. Lese- og skrivevanskar $i$ vidaregåande skole. Oslo: Cappelen Akademisk Forlag.

Møller, J., Prøitz, T. S. \& Aasen, P. (2009). Kunnskapløftet - tung bør å bcere. Underveisanalyse av styringsreformen $i$ skjceringspunktet mellom politikk, administrasjon og profesjon. RAPPORT 42/2009.

Maagerø, E. \& Karlsen, L. (2010). Lesing i matematikk. I D. Skjelbred \& B. Aamotsbakken (Red.), Lesing av fagtekster som grunnleggende ferdighet (s. 217-270). Oslo: Novus forlag.

Maagerø, E. \& Skjelbred, D. (2010). De mangfoldige realfagstekstene. Om lesing og skriving i matematikk og naturfag. Bergen: Fagbokforlaget.

Nortvedt, G. (2013). Leseforståelse og matematikk. Bedre skole, 10(1), 27-31.

O'Halloran, K. (2004). Mathematical discourse. Language, symbolism and visual images. New York: Continuum.

Opsal, H. (2013). Bruk av elevbøker $i$ matematikk på ungdomssteget: ein kasusstudie (Doktoravhandling). Kristiansand: Universitetet i Agder.

Otnes, H. (2015). Tildelte skriverroller og posisjoner i skriveoppgaver på mellomtrinnet. I H. Otnes (Red.), $A$ invitere elever til skriving. Ulike perspektiver på skriveoppgaver (s. 243--259). Bergen: LNU/Fagbokforlaget.

Pugalee, D. K. (2004). A comparison of verbal and written descriptions of students' problem solving processes. Educational Studies in Mathematics, 55(1-3), 27-47.

Smidt, J. (2011). Ti teser om skriving i alle fag. I J. Smidt, R. Solheim \& A. J. Aasen (Red.), På sporet av god skriveopplcering - ei bok for leerere $i$ alle fag (s. 9-41). Trondheim: Tapir Akademisk Forlag.

Vavik, L., Andersland, S., Arnesen, T. E., Arnesen, T., Espeland, M., Flatøy, I., ... \& Tuset, G. (2010). Skolefagundersøkelsen 2009. Utdanning, skolefag og teknologi. Hovedrapport. Haugesund: Høgskolen Stord/ Haugesund. 